\title{
Xenogeneic Mesenchymal Stem Cells in the Formation of Hyaline Cartilage in Osteochondral Goat Failure
}

\author{
Laís Meireles Costa Silva, Mariá Andrade de Carvalho Rocha, Marllos Henrique Vieira Nunes, \\ Brenda Lurian do Nascimento Medeiros, Yulla Klinger de Carvalho Leite, Huanna Waleska Soares Rodrigues, \\ Marcelo Campos Rodrigues, Hermínio José da Rocha Neto, \\ Maria Acelina Martins de Carvalho \& Napoleão Martins Argôlo Neto
}

\begin{abstract}
Background: Osteochondral knee failures are among the most common causes of disability among the elderly human population and animal athletes. The xenogeneic transplantation of mesenchymal stem cells is a questionable therapeutic alternative that, despite the low expression of Major Histocompatibility Complex type II by these cells, still has relevant uncertainties about the safety and clinical efficacy. The main objective of the present study was to investigate whether the xenogeneic transplantation of mesenchymal stem cells induces hyaline cartilage formation, without histopathological evidence of rejection, in osteochondral failures of goats.

Materials, Methods \& Results: Five female goats were used, submitted to three surgical osteocondral failures in the right knee, treated with xenogenic mesenchymal stem cells of dental pulp, xenogenic platelet-rich plasma and hemostatic sponge of hydrolyzed collagen, respectively. The lesions were evaluated after 60 days of treatment, aiming to identify the presence of hyaline cartilage or fibrocartilage and the subchondral bone pattern (regenerated or disorganized). Transplantation of xenogenic mesenchymal stem cells induced predominant formation of hyaline cartilage $(P<0.05)$, with no histopathological evidence of inflammation when compared to the other treatments. Therapies with xenogeneic platelet-rich plasma and hemostatic sponge of hydrolyzed collagen induced greater formation of fibrocartilaginous cartilage, with no significant difference between them $(P>0.05)$. Macroscopically, the lesions of the stem cell treated group showed formation of firm repair tissue, opaque staining, integrated with adjacent cartilage and with the failure filling almost completely. The groups treated with PRP and hemostatic sponge of hydrolyzed collagen presented, on average, partial filling of the lesion, with irregular shape and darkened coloration.

Discussion: The absence of macroscopic and histopathological evidences of an inflammatory process on the surface and in the internal portion of the osteochondral lesions treated with xenogeneic stem cells, probably due to the low expression of Major Histocompatibility Complex type II by these cells, which would theoretically induce low rejection response. Such observations are of great importance, since graft-versus-host disease syndrome is a serious condition, responsible for the low therapeutic efficacy with transplantation of cells or grafts in humans. The formation of fibrocartilage, although without macro and microscopic evidence of degeneration or necrosis, in the osteochondral failures treated with PRP and hemostatic collagen sponge suggest that paracrine factors of the local microenvironment of the osteochondral failure are possibly responsible for the formation of fibrocartilaginous tissue or by inhibition of normal cartilage formation. The fibrocartilage formed in the Plasma and Control groups, contributed to the commitment in the filling of the lesion, contrasting with the almost complete fill of the lesions treated with stem cells. The xenotransplantation of mesenchymal stem cells induced formation of hyaline cartilage and did not promote histopathological evidence of rejection in osteochondral lesions of goat knees. The treatments with PRP and hemostatic sponge of hydrolyzed collagen induced greater formation of fibrocartilaginous cartilaginous surface in the osteochondral failures.
\end{abstract}

Keywords: mesenchymal stem cells, hyaline cartilage, goat. 


\section{INTRODUCTION}

Along the last decade, the use of mesenchymal stem cells for the purpose of bone and joint regeneration was intensively investigated [24,31]. In addition to the bone marrow, adipose tissue and dental pulp have been used as source of collection [14,26], and high in vitro plasticity of these cells have been demonstrated in mesodermal and non-mesodermal tissues [20,27].

Xenogeneic stem cell transplantation for treatment of osteochondral lesions is a therapeutic alternative that still has relevant uncertainties about clinical safety and efficacy [26]. However, a recent study has demonstrated the effective contribution of this alternative in murine model [18].

Biodegradable materials such as hemostatic collagen sponges have been used as scaffolds for repair of bone failures, especially in human dentistry [16], but its effectiveness as a carrier for mesenchymal stem cells is unknown.

In addition, platelet-rich plasma is a potent osteoinducer, rich in growth factors capable to increase mitotic activity, activate fibroblasts, inducing angiogenesis, and other features [3,19,21].

The objective of this study was to investigate the effect of xenogenic transplantation of mesenchymal stem cells on the formation of hyaline cartilage, compared to treatments with xenogenic platelet-rich plasma and hemostatic collagen sponge, in osteochondral failures of goats.

\section{MATERIALS AND METHODS}

\section{Animals}

Two animals were exclusively used as donors of stem cells and blood plasma and five animals to compose the experimental groups of the preclinical study.

One male agouti (Dasyprocta primnolopha) was used as stem cells donor and one adult equine, with hematimetric values within the standard of normality for the species [10] and a total platelet count of $200 \times 103 / \mathrm{mm}^{3}$ or greater was used as a donor of blood plasma.

For the preclinical study, five native female goats (Capra hircus), clinically healthy, non-breed, pluriparous, non-pregnant, three years old and average weight of $35.5 \pm 1.5 \mathrm{~kg}$ were used. The goats were fed with commercial food ${ }^{1}$ for the species, in addition to voluminous at will with supply of forage brachiaria grass and leguminous leucena, mineral salt and water ad libitum.

\section{Obtaining of mesenchymal stem cells}

Mesenchymal stem cells (MSC) were previously isolated from the dental pulp of an agouti [8]. The dental pulp of a lower incisor tooth was washed in sterile saline phosphate buffer solution $\left(\mathrm{PBS}^{2}\right)$ $0.01 \mathrm{M} \mathrm{pH} 7.4$, supplemented with $3 \%$ penicillinstreptomycin ${ }^{3}$ and mechanically dissociated into the Dulbecco's Modified Eagle's (F12 DMEM) ${ }^{4}$ culture medium, supplemented with $20 \%$ fetal bovine serum ${ }^{3}$, $1 \%$ penicillin-streptomycin ${ }^{3}$, L-glutamine ${ }^{3}$ and nonessential amino acids ${ }^{3}$. The material was incubated at $5 \% \mathrm{CO}_{2}$ and $37^{\circ} \mathrm{C}$ and the cells cultured and expanded until the fourth passage. Cells were characterized by analyzing the expression of the CD34, CD14, CD45, CD73, CD79, CD90 and CD105 markers. Subsequently, mesenchymal stem cells were cryopreserved in a medium consisting of $45 \% \mathrm{~F}^{2} 2 \mathrm{DMEM}^{4}$ supplemented with $45 \%$ fetal bovine serum ${ }^{3}$ and $10 \%$ dimethyl sulfoxide $^{5}$. Cells remained cryopreserved for two years until thawed in $37^{\circ} \mathrm{C}$ water bath, viability was assessed by the trypan blue method and expanded until they reached $80 \%$ confluency.

\section{Interaction assay between stem cells and hemostatic sponge}

Three aliquots of $1 \times 10^{4}$ cells $/ \mathrm{mL}$ were cultured with a $3 \times 1 \mathrm{~mm}$ sample of a sterile hemostatic sponge of hydrolyzed collagen ${ }^{6}$ until they reached $80 \%$ confluence. The culture wells were evaluated and photographed to evaluate the interaction between cells and hemostatic sponge. Subsequently, the sponge fragment was removed and the mesenchymal stem cells were trypsinized and evaluated for cell viability [8]. The fragments of the hemostatic sponge were fixed in $5 \%$ formaldehyde ${ }^{7}$ alone for $24 \mathrm{~h}$, dehydrated in increasing concentrations of alcohol ${ }^{7}(30 \%, 55 \%$, $70 \%, 88 \%, 96 \%$ ), diaphanized in $\mathrm{xylol}^{8}$, included in histological paraffin ${ }^{9}$ and sectioned with a rotary microtome $^{10}$, adjusted to $4 \mu \mathrm{m}$ thick. Slices were fixed in glass slide, stained by Hematoxylin \& Eosin and analyzed by binocular optical microscope ${ }^{11}$ for evaluation of cell adhesion.

\section{Obtaining of platelet-rich plasma}

The blood was immediately processed according to the methodology described [3]. The concentra- 
tion of whole blood platelets was measured, followed by centrifugation of the sample at $600 \mathrm{~g}$ for five min. For each $25 \mu \mathrm{L}$ of platelet-rich plasma obtained, $25 \mu \mathrm{L}$ of $10 \%$ calcium gluconate was added, kept in a water bath at $37^{\circ} \mathrm{C}$ until the plasma was gelled.

\section{Induction of osteochondral lesions in goats}

All animals were submitted to antibiotic therapy with enrofloxacin ${ }^{12}(2.5 \mathrm{mg} / \mathrm{kg})$ by intramuscular route and $2 \mathrm{~h}$ of water fasting and feeding of $6 \mathrm{~h}$. The animals were sedated with intramuscular $2 \%$ xylazine $^{13}(0.1$ $\mathrm{mg} / \mathrm{kg})$, induced with intravenous propofol ${ }^{14}(5 \mathrm{mg} / \mathrm{kg})$ and spinal anesthesia were performed with morphine ${ }^{14}$ $(0.1 \mathrm{mg} / \mathrm{kg})$ associated to $0.5 \%$ isobaric bupivacaine ${ }^{14}$ in the volume of $0.2 \mathrm{~mL}$, followed by intubation and anesthetic maintenance with Isoflurane ${ }^{14}$ diluted in $100 \%$ oxygen. The surgical field was delimited on the right femur-tibial-patellar joint. An arthrotomy of the medial parapatellar region was performed, the subcutaneous tissue was incised to access the patella, which was laterally displaced by manual compression to expose the femoral trochlea. With the aid of an orthopedic drill1 ${ }^{5}$ equipped with a $4 \mathrm{~mm}$ steel drill ${ }^{16}$, three osteochondral lesions $4 \mathrm{~mm}$ in diameter and $6 \mathrm{~mm}$ deep were produced, two in the distal part of the femoral trochlea and one in the proximal part. After immediate treatment of osteochondral failure, the joint capsule were closed with single interrupted suture with 2-0 nylon monofilament yarn ${ }^{17}$. Surgical plans were approximated with Sultan interrupted suture plane and skin with single interrupted suture, both using 2-0 nylon monofilamentar yarn ${ }^{17}$.

After the surgery, the animals were medicated with tramadol hydrochloride ${ }^{18}(2 \mathrm{mg} / \mathrm{kg})$ by intramuscular route twice daily for five days, enrofloxacin ${ }^{12}(2.5$ $\mathrm{mg} / \mathrm{kg}$ ) by subcutaneous route once daily for 10 days and meloxicam ${ }^{19}(0.2 \mathrm{mg} / \mathrm{kg})$ by intramuscular route once daily for 5 days. Surgical wounds were cleaned daily with sterile saline solution and topical application of allantoin and chlorhexidine ointment ${ }^{20}$.

\section{Treatments}

Each lesion represents an experimental group of treatment, coexisting all groups in each animal, totaling 15 lesions and 5 replicates for each treatment. The animals were treated once in the trans operative, according to the experimental groups: Control group: distal left lesion of the trochlea, treated with filling of the osteochondral failure with $3 \mathrm{~mm}$ of sterile hemostatic sponge of hydrolyzed collagen soaked in sterile physiological solution. MSC group: proximal inferior lesion of the trochlea, treated with $10^{6} \mathrm{MSC} /$ $\mathrm{mL}$ infused into $3 \mathrm{~mm}$ of sterile hemostatic sponge of hydrolyzed collagen. Platelet Rich Plasma (PRP) group: distal right lesion of the trochlea, treated with platelet rich plasma at a concentration of $1.3 \times 10^{6} / \mathrm{mm}^{3}$ infused in $3 \mathrm{~mm}$ of hemostatic sponge.

\section{Histological procedure}

After 60 days of treatment, the animals were identified, weighed and submitted to euthanasia by sedation with ketamine ${ }^{20}(30 \mathrm{mg} / \mathrm{kg})$ given intravenously and after confirmation of unconsciousness, administration of potassium chloride ${ }^{21}$ by intravenous route. The lesions were identified, serrated and fixed individually in $10 \%$ formaldehyde ${ }^{7}$ buffered for $48 \mathrm{~h}$. The samples were decalcified in $20 \%$ hydrochloric acid solution for ten days and $5 \%$ for five days. The decalcified fragments were processed histologically in a conventional manner [24]. The samples were included in histological paraffin ${ }^{9}$, sectioned with a rotary microtome ${ }^{10}$, adjusted to $5 \mu \mathrm{m}$ thick. Slices were fixed in glass slide, stained by Hematoxylin \& Eosin and analyzed in binocular optical microscope ${ }^{11}$.

\section{Microscopic evaluation}

For each osteochondral lesion, the scores were assigned: 0 -absence of tissue covering the lesion, 1-formation of fibrocartilage and 2-formation of hyaline cartilage.

\section{Statistical analysis}

Statistical analysis was performed with Bioestat $^{\circledR}$ software v. 5.9, applying the Kruskal-Wallis nonparametric analysis of independent samples, followed by the Dunn station median comparison test, adopting a level of rejection of the null hypothesis of $5 \%(P \leq 0.05)$.

\section{RESULTS}

Goats remained clinically healthy after induction of osteochondral lesions, without clinical evidence of anorexia, fever and/or apathy. It was identified evident claudication in the affected joint, of moderate intensity, without significant alteration of the cardiorespiratory frequency, according to the physiological patterns for the species $[6,11]$.

A homogeneous stem cell culture was obtained from the 10th day of culture, with fusiform morphology, forming a monolayer on the 22nd day of culture. Flow 
cytometry identified that mesenchymal stem cells were positive for CD34, CD73, CD90 and CD105 markers, and were negative for CD14, CD45 and CD79 markers (Figure 1). After the thawing of mesenchymal stem cells, after two years, $80 \%$ of viability was identified.

The culture medium of mesenchymal stem cells with a sterile hydrolyzed collagen sponge fragment identified that the cells adhered to the sponge matrix after 10 days of incubation (Figure 2A and B) and the evaluation of the mean cell viability identified after removal of the fragment was $95 \%$.

The histological evaluation of the same fragment of sponge identified the presence of few mononuclear cells adhered to the substrate of the same, with intact nucleus and loosely condensed chromatin. The cells were sparsely distributed between the pores of the sponge, isolated from each other.

An equine plasma of high platelet concentration and smaller in volume than whole blood was obtained. As the sample was sequentially centrifuged and the haematological and superficial fractions of the plasma were withdrawn, a product exclusively composed of concentrated platelets of $1.3 \times 10^{6} / \mathrm{mm}^{3}$, representing $82 \%$ of the initial platelet volume concentration, was obtained but in the volume of $0.4 \mathrm{~mL}$, 10 times lower than the initial one.

After 60 days of treatment, it was observed that the lesions of the stem cells group presented formation of firm repair tissue, opaque staining, integrated with the adjacent cartilage and filling the failure almost in its entirety. Among the failures treated with PRP, on average, there was partial integration of the failure with the adjacent cartilage, with partial and symmetrical filling of the lesion and irregular and depressed lesion surface, with darkened, well circumscribed staining, surrounded by macroscopically healthy hyaline cartilage. The lesions treated with hemostatic sponge of hydrolyzed collagen presented, on average, partial filling of the lesion, uneven articular surface and reddish coloration (Figure $3 \mathrm{~A}$ and $\mathrm{B}$ ).

Histopathological differences $(P<0.05)$ were observed between the lesions treated with xenogenic mesenchymal stem cells and the other treatments. In the MSC group there was an average predominance of the presence of hyaline cartilage and a smooth cartilaginous surface in the lesions evaluated. In the lesions of the Platelet Rich Plasma and Control groups, the average prevalence of fibrocartilage was observed in relation to the hyaline cartilage, with an irregular and depressed articular surface (Figure $3 \mathrm{C}$ and D). No differences $(P<0.05)$ were observed between the lesions treated with xenogenic platelet rich plasma and hemostatic sponge of hydrolyzed collagen.

The osteochondral lesions of all treatment groups showed regenerated, subchondral bone characterized by the presence of mature lamellar bone, composed of osteocytes and the organization of trabecular bone tissue without the presence of osteoblasts.

It was not identified histopathological characteristics of inflammatory activity and necrosis in none of the treated osteochondral failures.
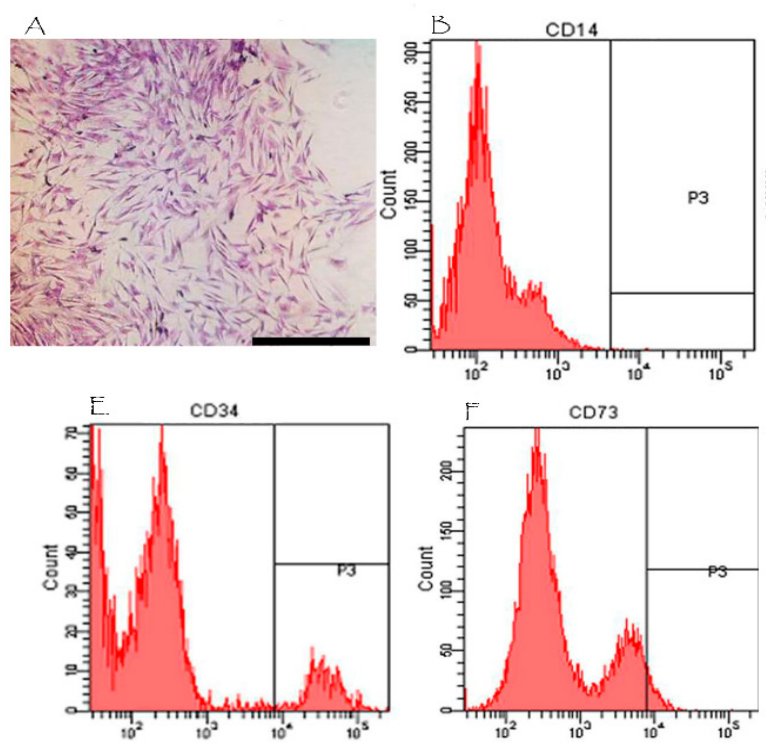
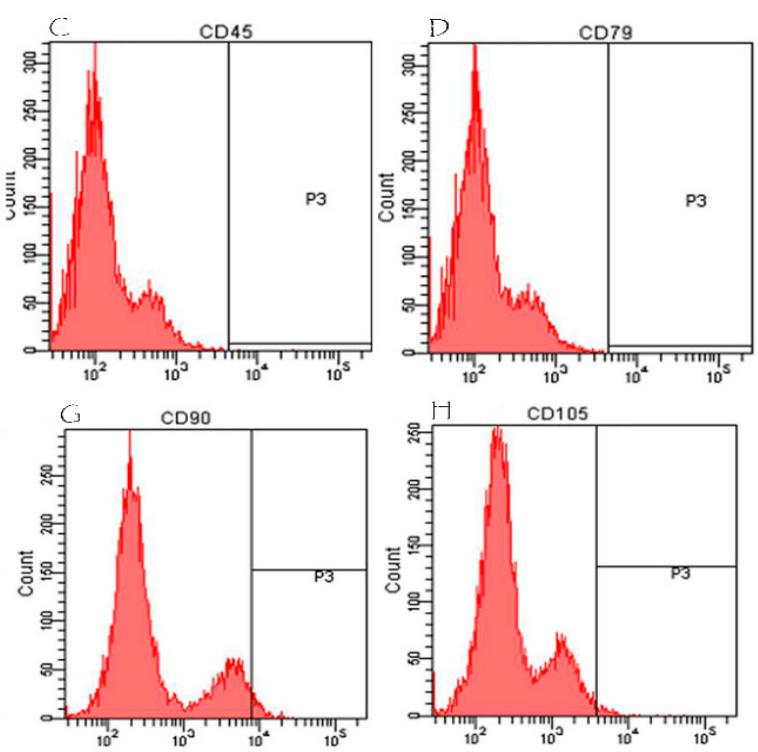

Figure 1. Flow cytometry of mesenchymal stem cells in the fourth passage, derived from the dental pulp of agoutis (Dasyprocta primnolopha). A- Cells of fibroblastóid morphology and basophilic cytoplasm [Giemsa, Barra= $100 \mu \mathrm{m}]$. B, C, D- Negative expression for hematopoietic markers. E, F, G, H- Positive expression for markers commonly used for mesenchymal stem cell cultures. 


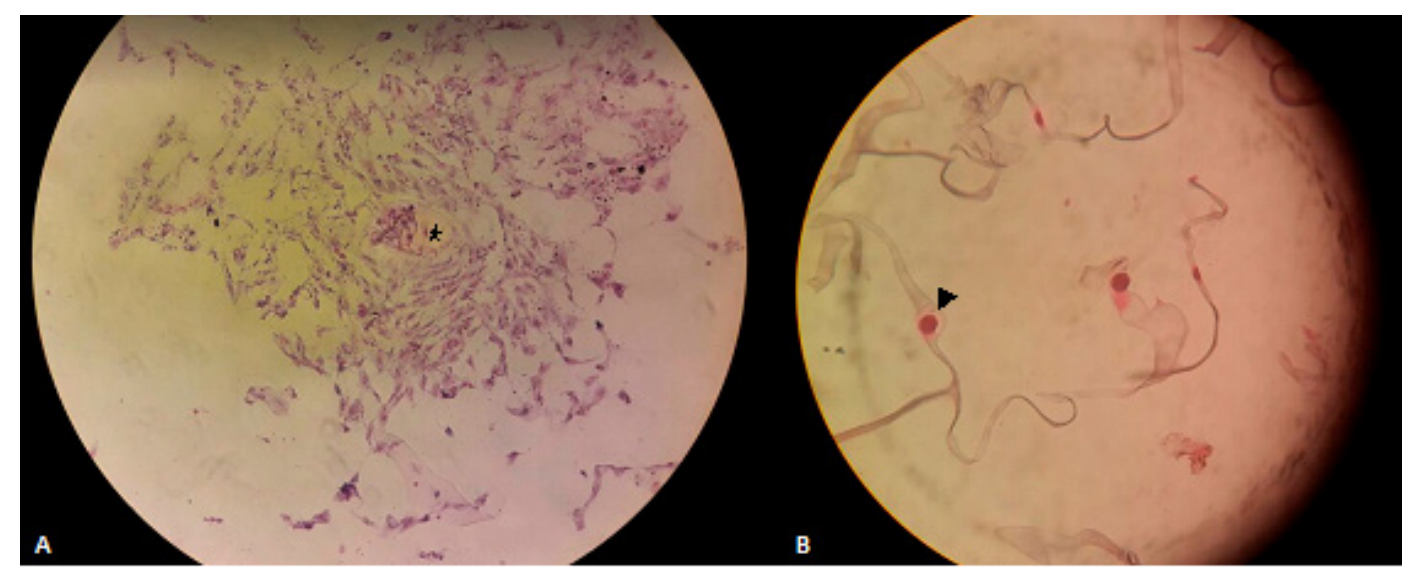

Figure 2. Interaction between mesenchymal stem cells and hemostatic sponge of hydrolyzed collagen. A- Cells fixed with $10 \%$ buffered paraformoldehyde and stained with May-Grunwald Giemsa, bordering the sponge fragment $(*)$ [20x]. B- Histological section of the sponge after 10 days of incubation in culture with mesenchymal stem cells. The presence of a mononuclear cell $(\boldsymbol{\Delta})$, of loose chromatin, adhered to the convolutions of the sponge matrix [Hematoxylin \& Eosin 40x] is identified.

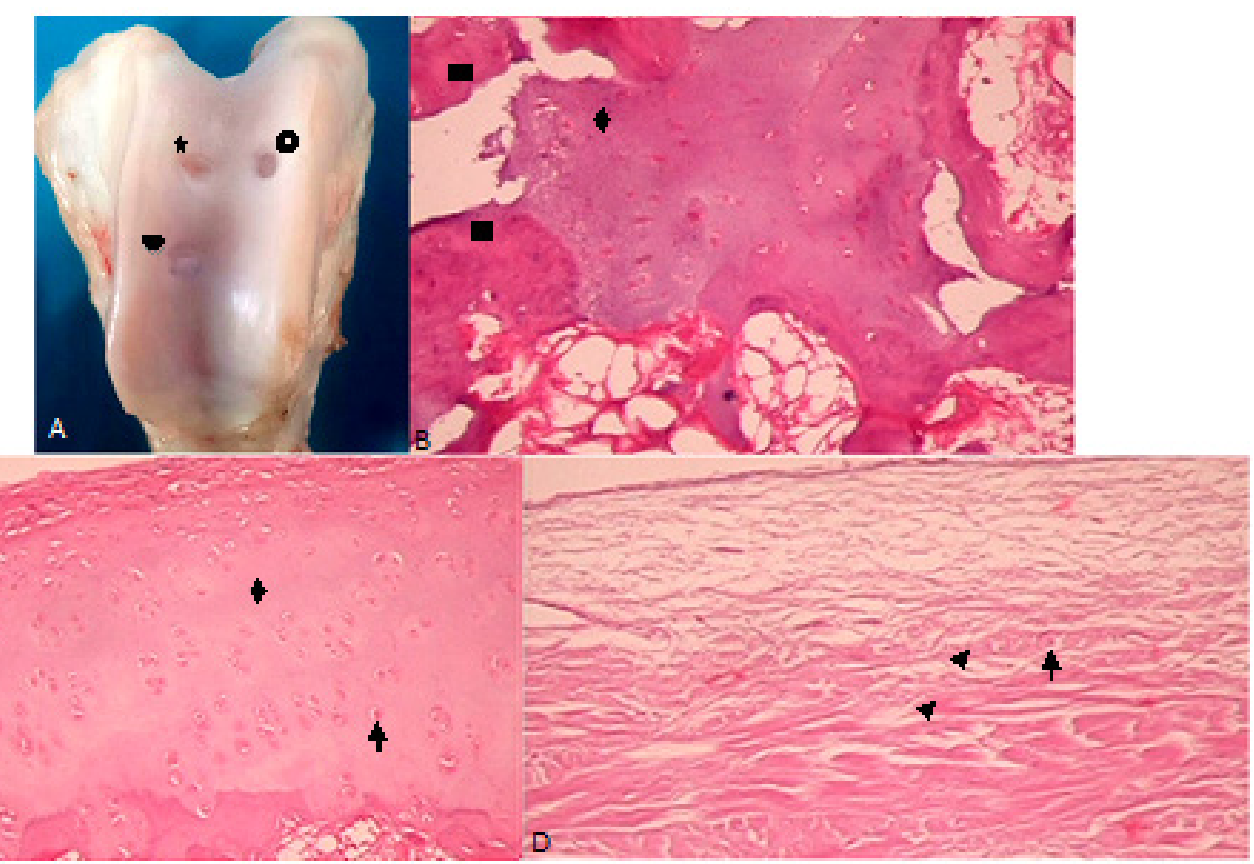

Figure 3. Macro and microscopic appearance of osteochondral lesions in femoral trochlea of goats after 60 days of treatment. A- Lesion treated with collagen hemostatic sponge $\left(^{*}\right)$ presented partial filling of the lesion, with an uneven articular surface and reddish color. Lesion treated with xenogenic mesenchymal stem cells $(\bullet)$ presented complete lesion filling, with opaque staining repair tissue and integrated with the adjacent cartilage. Lesion treated with xenogenic platelet rich plasma (a) presented partial lesion filling, with irregular and depressed surface, with darkened color, surrounded by macroscopically healthy hyaline cartilage. B- Joint surface with presence of hyaline cartilage ( $)$ arranged in irregular shape and surrounded by bone tissue ( $\mathbf{m}$ ) in the group treated with collagen hemostatic sponge. C- Joint surface with presence of hyaline cartilage $(\diamond)$ in the group treated with xenogenic mesenchymal stem cells, characterized by the presence of chondrocytes $(\uparrow)$ arranged in isogenic groups in the cartilaginous matrix. D- Joint surface with presence of fibrocartilage in the group treated with xenogenic platelet rich plasma, characterized by thick collagen fibers $(\boldsymbol{\Lambda})$ between the rows of chondrocytes $(\uparrow)$. Hematoxylin-eosin staining [10x magnification].

\section{DISCUSSION}

The choice of goat as an animal model for the present study is due to the anatomical dimensions of the knee, similar to the dimensions of the human knee [5], allowing adequate exposure of the articular surface, favoring surgical manipulation.
The animals resumed spontaneous walking and showed appetite soon after anesthetic recovery. Similar results were described [7], using an equivalent anesthetic protocol, reiterating the effectiveness of the therapeutic pain management adopted in this study. The association between spinal local anesthesia associated 
with morphine, probably contributed to a postoperative period without clinical complications, associated with analgesic, antibiotic and anti-inflammatory use, as previously proposed [34].

The diameter chosen for the osteochondral lesions in this experiment was $4 \mathrm{~mm}$ in diameter, as recommended [15,34], according to them, lesions smaller than $3 \mathrm{~mm}$ may predispose to spontaneous repair by fibrocartilaginous tissue.

The use of hemostatic sponges such as scaffold for studies with repair of bone failures has already been described in previous research, both in humans and in animals $[4,12]$, corroborating to justify the choice of this substrate for the model introduced. In addition, it is widely used in humans, possessing authorizations from governmental agencies of surveillance for commercialization [32], and is then adopted as the gold standard in this study.

The in vitro biocompatibility assay between mesenchymal stem cells and a fragment of the hemostatic sponge of hydrolyzed collagen demonstrated that there was no apparent cytotoxic effect on the cells, since the cultivation cells adhered to the fragment were identified, with average viability of $95 \%$ identified by the trypan blue exclusion technique (Figure 2A and B). This technique is used to determine the number of viable cells in a cell suspension. It is based on the principle that viable cells (with intact cell membrane) are able to exclude trypan blue, which crosses the membrane, from its cytosol. While unviable cells (with compromised cell membrane), such as in advanced apoptotic state, are unable to exclude it [9].

Cells adhered to the substrate of the fragment were identified after histological processing, denoting that the substrate matrix provided an environment favorable to cell adhesion. Corroborates this observation, a contemporary study that inferred that cell-matrix interaction influences cell viability, which may induce apoptosis or not, depending on the chemical nature of the material used [37].

However, it was not observed a high concentration of cells adhered to the hydrolyzed collagen sponge, fact that remains incomprehensible by the authors of the present study. It is believed that the pore size of the sponge may have favored the low retention of cells in the substrate, since the cell viability observed in the biocompatibility assay was
95\%. Previous studies contribute to this hypothesis by indicating that the pore size and pore interconnectivity of a scaffold is a determinant factor for cell fixation, and should be compatible with the dimensions of the cell population used [23,29]. However, it was not performed evaluation of the hemostatic sponge of hydrolyzed collagen by scanning electron microscopy, and it was not possible to infer precisely the interference of the physical structure of the scaffold on the cellular retention. Complementary studies are needed to conduct this analysis, in addition to the reduction test of the bromide test 3- [4,5-dimethylthiazol-2-yl] -2,5-diphenyltetrazolium (MTT) to blue of formazan, as proposed in contemporary studies $[1,13]$.

In the in vitro biocompatibility study, it was evident the alteration of the cellular morphology of MSC. This effect was expected, since MSCs are adherent mononuclear cells that assume fibroblastoid or fusiform morphology only when on a regular surface in the culture medium like in controlled incubation conditions [3]. Since the porous surface of the irregular hemostatic sponge, MSC was visualized in mononuclear oval form.

After 60 days of observation, they were not evident macro or microscopic traces of the hemostatic sponge inside the osteochondral failures evaluated, corroborating with previous reports of biocompatibility and resorption in vivo [30].

It was not observed macroscopic and histopathological evidence of inflammatory process on the surface and in the internal portion of the osteochondral lesions analyzed in this study. Such observations are of great importance, since graft-versus-host disease syndrome is an acute or hyperacute condition, responsible for the low therapeutic efficacy with transplantation of cells or grafts in humans [35]. According to these authors, approximately $40 \%$ to $50 \%$ of human patients undergoing bone marrow transplantation develop such a clinical condition [17].

It was expected absence of response macro and histopathological of rejection in osteochondral failures treated with hydrolyzed collagen sponge of porcine origin, since it is already commercially used in humans, as observed in contemporary studies $[32,33]$.

However, the inexistence of tissue evidence of rejection in the osteochondral failures treated with PRP 
and MSC is considered a positive preliminary datum, although it can not be inferred that this result is reproduced in other animals, under other methodological conditions of study.

In the present study, osteochondral failures treated with PRP and hydrolyzed collagen sponge induced formation of fibrocartilaginous cartilage, without macro and microscopic evidence of degeneration or necrosis. A similar result was obtained [7], using PRP in osteochondral lesion of sheep knee, in which there was predominance of fibrocartilage on the articular surface. Paracrine factors of the local microenvironment of the osteochondral failure are possibly responsible for the formation of fibrocartilaginous tissue or inhibition of normal cartilage formation [34]. The greater occurrence of the fibrocartilaginous surface in the Platelet Rich Plasma and Control groups contributed to the commitment in the filling of the lesion, observed in the macroscopic evaluation, where it was verified integration and partial filling of the failure, in an irregular and depressed form, with coloration varying darkened to reddish, respectively.

The PRP has been used for about 20 years with the objective of accelerating the healing and regeneration of bone resulting from surgical procedures in humans. The plasma has a high concentration of platelets in a reduced plasma volume, besides growth factors that behave like molecules of cellular adhesion in the processes of epithelial migration, osteoinduction and in the formation of bone matrix in the connective tissue. Due to the high concentration of growth factors that stimulate cell migration and tissue remodeling, it is believed that the xenogeneic use of PRP may be responsible for the greater formation of fibrocartilage, as suggested in previous studies $[28,38]$. However, as there was no histopathological inflammatory response, new studies using immunohistochemical techniques to elucidate the influence of xenogenic PRP on osteocartilaginous tissue are suggested.

The effect of MSC on bone tissue repair had been described in contemporary studies $[2,25,33]$. According to these authors, MSCs are multipotent somatic progenitor cells, capable of originating mesodermal and not mesodermal tissues. The differentiation of these cells in vitro into osteoblasts has been induced in several previous studies $[3,8]$.
The xenogeneic MSCs that remained adhered to the hemostatic sponge induced greater formation of hyaline cartilage $(P<0.05)$ when compared to the other treatments. In addition, the osteochondral failures treated with these cells did not present macro and histopathological evidence of degeneration, inflammation and/or tissue necrosis.

The MSCs do not express significant levels of the class II histocompatibility complex and do not have costimulatory molecules, such as B7-1 and B7-2, theoretically exhibiting a low rejection response [36]. However, MSCs express MHC class I and some lineages express binding CD40 and CD40 molecules, which may in some circumstances be identified by Toll Like Receptors which in turn could induce immunogenic activation [22]. Given such controversies, preclinical studies, as presented here, are of great relevance in assessing the clinical and histopathological response of MSCs in osteochondral failures.

It was considered the maintenance of joint surface integrity and neoformation of hyaline cartilage in the knee lesions of the animals treated in this study very satisfactory, since in the repair of osteochondral lesions it is expected that there is no significant recruitment of osteocartilaginous tissue, so as not to inducing fibrocartilage formation, which could compromise joint function [38].

In this study, a presence of mature subchondral bone was evidenced in all the treatments performed, demonstrating that there was a satisfactory repair of the deep part of the osteochondral lesion against the treatments used, without evidence of deleterious effect in the cartilaginous surface.

\section{CONCLUSIONS}

Mesenchymal stem cell xenotransplant induced hyaline cartilage formation and did not promote histopathological evidence of rejection in osteochondral lesions of goat knees.

The sterile hemostatic sponge of hydrolyzed collagen presented biocompatibility with the xenogeneic MSCs, preserving its viability.

The treatments with PRP and hemostatic sponge of hydrolyzed collagen induced greater formation of fibrocartilaginous cartilaginous surface in the osteochondral failures. Macroscopically, it was evident filling of the inferior lesion for other treatments and discrepant coloring of normal cartilage. 
MANUFACTURERS

${ }^{1}$ Agromix Nutrição Animal. Jaboticabal, SP, Brazil.

${ }^{2}$ Cultilab Materiais para Cultura de Células Ltda. Campinas, SP, Brazil.

${ }^{3}$ Life Technologies Corporation. Grand Island, NY, USA.

${ }^{4}$ Thermo Fisher Scientific. Waltham, MA, USA.

${ }^{5}$ Aldrich Corporation. Saint Louis, MO, USA.

${ }^{6}$ Technew Comércio e Indústria Ltda. Quintino, RJ, Brazil.

${ }^{7}$ Indalabor Laboratório Farmacêutico Ltda. Dores de Indaiá, MG,

Brazil.

${ }^{8}$ Quimesp Química. Guarulhos, SP, Brazil.

${ }^{9}$ Única Científica. São Caetano do Sul, SP, Brazil.

${ }^{10}$ Leica Biosystems. São Paulo, SP, Brazil.

${ }^{11}$ Olympus Optical do Brasil Ltda. São Paulo, SP, Brazil.

${ }^{12}$ Chemitec Agro-veterinária Ltda. Ipiranga, SP, Brazil.

${ }^{13}$ Ceva Saúde Animal. Paulínia, SP, Brazil.

${ }^{14}$ Cristália Produtos Químicos Farmacêuticos Ltda. Itapira, SP, Brazil.

${ }^{15}$ Brasmed Empresa Brasileira de Cirurgia Veterinária Ltda. Paulínia, SP, Brazil.

${ }^{16}$ Grupo OVD. Barbalha, CE, Brazil.

${ }^{17}$ Ethicon Inc. Somerville, NJ, EUA.

${ }^{18}$ Hipolabor Farmacêutica Ltda. Eynard, MG, Brazil.
${ }^{19}$ Ouro Fino Saúde Animal. Cravinhos, SP, Brazil.
${ }^{20}$ Virbac Indústria e Comércio Ltda. Jurubatuba, SP, Brazil.
${ }^{21}$ Halexistar Indústria Farmacêutica. Goiânia, GO, Brazil.

Acknowledgements. Coordination for the Improvement of Higher Level or Education Personnel (CAPES); National Council for Scientific and Technological Development (CNPq); University Veterinary Hospital of the Federal University of Piauí (UFPI); Sector of Zootechnia of the Federal University of Piauí.

Ethical approval. This experiment was approved and performed under the guidelines of Ethics Committee in Animal Experiments (CEEA) of the Federal University of Piauí (UFPI), according to statement $\mathrm{n}^{\circ} 120 / 2015$, in accordance to the regulations of the Brazilian Collegiate of Animal Experimentation (COBEA).

Declaration of interest. The authors report no conflicts of interest. The authors alone are responsible for the content and writing of the paper.

\section{REFERENCES}

1 Açil Y., Zhang X., Nitsche T., Möller B., Gassling V., Wiltfang J. \& Gierloff M. 2014. Effects of different scaffolds on rat adipose tissue derived stroma cells. Journal of Cranio-Maxillo-Facial Surgery. 42(6): 825-834.

2 Argôlo Neto N.M., Del Carlo R.J., Monteiro B.S., Nardi N.B., Chagastelles P.C., Brito A.F.S. \& Reis A.M.S. 2012. Role of autologous mesenchymal stem cells associated with platelet-rich plasma on healing of cutaneous wounds in diabetic mice. Clinical and Experimental Dermatology. 37(5): 544-553.

3 Argôlo Neto N.M., Feitosa M.L.T., Sousa S.S., Fernandes P.B., Pessoa G.T., Bezerra D.O., Almeida H.M., Carvalho Y.K.P., Rocha A.R., Silva L.M.C. \& Carvalho M.A.M. 2016. Isolation, expansion, differentiation and growth kinetics essay in mesenchymal stem cells culture from the bone marrow of collared peccaries (Tayassu tajacu). Acta Scientiae Veterinariae. 44(1): 1-11.

4 Berenguel I.A. 2006. Implantes das esponjas hemostáticas Gelfoam e Hemospon em alvéolos dentais em ratos após exodontia. Estudo histológico e histométrico comparativo. 108 f. Marília, SP. Dissertação (Mestrado em Odontologia) - Programa de Pós-graduação em Odontologia, Faculdade de Odontologia de Marília.

5 Brehm W., Aklin B., Yamashita T., Rieser F., Trüb T., Jakob R.P. \& Mainil-Varlet P. 2006. Repair of superficial osteochondral defects with an autologous scaffold-free cartilage construct in a caprine model: implantation method and short-term results. Osteoarthritis and Cartilage. 14(12): 1214-1226.

6 Cardoso E.C., Oliveira D.R., Dourado A.P., Araújo C.V., Ortalani E.L. \& Brandão F.Z. 2010. Peso e condição corporal, contagem de OPG e perfil metabólico sanguíneo de ovelhas da raça Santa Inês no periparto, criadas na região da Baixada Litorânea do Estado do Rio de Janeiro. Revista Brasileira de Ciência Veterinária. 17(2): 77-82.

7 Carneiro M.O., Barbieri C.H. \& Barbieri Neto J. 2013. Platelet-rich plasma gel promotes regeneration of articular cartilage in knees of sheeps. Acta Ortopédica Brasileira. 21(2): 80-86.

8 Carvalho Y.K.P., Argôlo Neto N.M., Ambrósio C.E., Oliveira L.J., Rocha A.R., Silva J.B., Carvalho A.A.M. \& Alves F.R. 2015. Isolation, expansion and differentiation of cellular progenitors obtained from dental pulp of agouti (Dasyprocta prymnolopha Wagler, 1831). Pesquisa Veterinária Brasileira. 35(6): 590-598.

9 Casaroto A.R., Sell A.M., Nagata J.Y., Brunetta E.V., Franco S.L. \& Hidalgo M.M. 2012. Manutenção da viabilidade das células mononucleares de sangue periférico humano em extratos e formulações de própolis. Acta Scientiarum Health Sciences. 34(1): 59-66.

10 Cunha A.P., Bello A.C.P.P., Leite R.C., Melo M.M., Braz G.F., Ribeiro A.C.C.L. \& Oliveira P.R. 2008. Avaliação de parâmetros clínicos e hematológicos de eqüinos submetidos a um programa de controle estratégico de Amblyomma cajennense (Fabricius, 1787) (Acari: Ixodidae). Arquivo Brasileiro de Medicina Veterinária e Zootecnia. 60(1): 113-120.

11 Daramola J.O., Adeloye A.A.A., Fatoba T.A. \& Soladoye A.O. 2005. Haematological and biochemical parameters of West African Dwarf goats. Livestock Research for Rural Development. 17(8): 3-4. 
12 Gabrielli M.A.C., Hochuli-Vieira E., Paleari A.G., Cerri P.S. \& Klüppel L.E. 2009. Avaliação histológica de agentes hemostáticos implantados em mandíbulas de coelhos. Revista de Cirurgia e Traumatologia Buco-maxilo-facial. 9(2): 97-106.

13 Galdino A.G.S., Oliveira E.M., Filippin-Monteiro F.B. \& Zavaglia C.A.C. 2014. Análise de ensaios in vitro do compósito de 50\% HA-50\% TiO2 fabricados pelo método da esponja polimérica. Cerâmica. 60(1): 586-593.

14 Huang G.T., Gronthos S. \& Shi S. 2009. Mesenchymal stem cells derived from dental tissues vs. those from other sources: their biology and role in regenerative medicine. Journal of Dental Research. 88(9): 792-806.

15 Jackson D.W., Lalor P.A., Aberman H.M. \& Simon T.M. 2001. Spontaneous repair of full-thickness defects of articular cartilage in a goat model. A preliminary study. The Journal of Bone and Joint Surgery American. 83(1): 53-64.

16 Jiang X., Wang Y., Fan D., Zhu C., Liu L. \& Duan Z. 2017. A novel human-like collagen hemostatic sponge with uniform morphology, good biodegradability and biocompatibility. Journal of biomaterials applications. 31(8): 10991107.

17 Krenger W., Hill G.R. \& Ferrara J.L.M. 1997. Cytokine cascades in acute graft-versus-host disease1. Transplantation. 64(4): 553-558.

18 Larocca T.F., Souza B.S.F., Silva C.A., Kaneto C.M., Alcantara A.C., Azevedo C.M., Castro M.F., Macambira S.G., Soares M.B.P \& Ribeiro-Dos-Santos R. 2013. Transplante de células mesenquimais de tecido adiposo na cardiopatia chagásica crônica experimental. Arquivo Brasileiro de Cardiologia. 100(5): 460-468.

19 Lenza M., Ferraz S.B., Viola D.C.M., Santos O.F.P., Cendoroglo Neto M. \& Ferretti M. 2013. Plasma rico em plaquetas para consolidação de ossos longos. Revista Einstein. 11(1): 122-127.

20 Li J.H., Liu D.Y., Zhang F.M., Wang F., Zhang W.K. \& Zhang Z.T. 2011. Human dental pulp stem cell is a promising autologous seed cell for bone tissue engineering. Chinese Medical Journal. 124(23): 4022-4028.

21 Lubowitz J.H. \& Poehling G.G. 2010. Shoulder, hip, knee, and PRP. Arthroscopy: The Journal of Arthroscopic and Related Surgery. 26(2): 141-142.

22 Marti L.C., Ribeiro A.A.F. \& Hamerschlak N. 2011. Immunomodulatory effect of mesenchymal stem cells. Einstein. 9(2): 224-228.

23 Murphy C.M., Duffy G.P., Schindeler A. \& O'brien F.J. 2016. Effect of collagen glycosaminoglycan scaffold pore size on matrix mineralization and cellular behavior in different cell types. Journal of Biomedical Materials Research Part A. 104(1): 291-304.

24 Monteiro B.S., Argôlo Neto N.M. \& Del Carlo R.J. 2008. Terapia celular em reparação óssea-aplicação clínica de células-tronco mesenquimais. Ciência Veterinária nos Trópicos. 11(2): 95-100.

25 Monteiro B.S., Del Carlo R.J., Argôlo Neto N.M., Nardi N.B., Carvalho P.H., Bonfá L.P., Chagastelles P.C., Moreira H.N., Viloria M.I.V. \& Santos B.S. 2012. Association of mesenchymal stem cells with platelet rich plasma on the repair of critical calvarial defects in mice. Acta Cirúrgica Brasileira. 27(3): 201-209.

26 Morad G., Kheiri L. \& Khojasteh A. 2013. Dental pulp stem cells for in vivo bone regeneration: A systematic review of literature. Archives of Oral Biology. 58(12): 1818-1827.

27 Morito A., Kida Y., Suzuki K., Inoue K., Kuroda N. \& Gomi K. 2009. Effects of basic fibroblast growth factor on the development of the stem cell properties of human dental pulp cells. Archives of Histology Cytology. 72(1): 51-64.

28 Moshiri A. \& Oryan A. 2013. Role of platelet rich plasma in soft and hard connective tissue healing: an evidence based review from basic to clinical application. Hard Tissue. 2(1): 6-7.

29 Murphy C.M. \& O'Brien F.J. 2010. Understanding the effect of mean pore size on cell activity in collagen-glycosaminoglycan scaffolds. Cell adhesion \& migration. 4(3): 377-381.

30 Oliveira G.K., Raiser A.G., Olsson D., Pippi N.L., Tognoli G.K, Trindade L.B., Santos Júnior E.B., Dezengrine R., Martins D.B., Salbego F.Z., Rappeti J. \& Sausen L. 2010. Células-tronco mononucleares autólogas e proteína óssea morfogenética na cicatrização de defeitos tibiais experimentalmente induzidos em cães. Arquivo Brasileiro de Medicina Veterinária e Zootecnia. 62(1): 72-79.

31 Pittenger M.F., Mackay A.M. \& Beck S.C. 1999. Multilineage potential of adult human mesenchymal stem cells. Science. 284(5411): 143-147.

32 Rocha A.L., Shirasu B.K., Hayacibara R.M., Magro-Filho O., Zanoni J.N. \& Araújo M.G. 2012. Clinical and histological evaluation of subepithelial connective tissue after collagen sponge implantation in the human palate. Journal of Periodontal Research. 47(6): 758-765. 
33 Rocha M.A.D.C., Silva L.M.C., Oliveira W.A.D., Bezerra D.D.O., Silva G.C.D., Silva L.D.S., Medeiros B.L.N, Baêta S.A.F., Carvalho M.A.M. \& Argolo Neto N.M. 2017. Allogeneic mesenchymal stem cells and xenogenic platelet rich plasma, associated or not, in the repair of bone failures in rabbits with secondary osteoporosis. Acta Cirurgica Brasileira. 32(9): 767-780.

34 Saw K.Y., Hussin P., Loke S.C., Azam M., Chen H.C. \& Tay Y.G. 2009. Articular cartilage regeneration with autologous marrow aspirate and hyaluronic acid: an experimental study in a goat model. Arthroscopy. 25(12): 1391-400.

35 Soares D.S., Freitas K., Barbosa G.M. \& Araújo M.C.S. 2007. Doença enxerto contra hospedeiro: relato de caso. Disciplinarum Scientia. 8(1): 91-113.

36 Souza C.F., Napoli P., Han S.W., Lima V.C. \& Carvalho A.C.C. 2010. Células-tronco mesenquimais: células ideais para a regeneração cardíaca? Revista Brasileira de Cardiologia. 18(3): 344-353.

37 Trappmann B. \& Chen C.S. 2013. How cells sense extracellular matrix stiffness: a material's perspective. Current opinion in biotechnology. 24(5): 948-953.

38 Yamada A.L.M., Alvarenga M.L., Brandão J.S., Watanabe M.J., Rodrigues C.A., Hussni C.A. \& Alves A.L. 2016. Arcabouço de PRP-gel associado a células tronco mesenquimais: uso em lesões condrais em modelo experimental equino. Pesquisa Veterinária Brasileira. 36(6): 461-467. 